\title{
The Meaning of Love in Balada Cinta Majnun Novel by Geidurrahman El-Mishry (Psychology of Literature)
}

\author{
Marsin $^{1}$, Ifan Iskandar ${ }^{2}$, and Siti Gomo Attas ${ }^{3}$ \\ \{marsin_pb16s2@mahasiswa.unj.ac.id ${ }^{1}$, ifaniskandar@unj.ac.id ${ }^{2}$, sitigomoattas@unj.ac.id $\left.{ }^{3}\right\}$ \\ ${ }^{1,2,3}$ Universitas Negeri Jakarta, Indonesia
}

\begin{abstract}
Abstarct. This study reports the results of the content analysis on Balada Cinta Majenun Novel by Geidurrahman El-Mishry about the love of the main character using the psychology of literature approach. The purpose of this study was to reveal the meaning of the main character's love based on Erich Fromm's love theory. The data used was the text in the novel. Reading and taking note were used to collect data. The data was classified based on the object of erotic love and divine love. Then, they were analyzed using the psychology of literature and interpreted using contextual meaning. The result showed that there was a love shift from erotic love to God love. It was influenced by the rejection of love and the concept of love that the main character owned as a result of following tharikat that later shaped his way of life into religion-oriented. His religious path, from love to the creatures that led to the path of God, gave rise to the desire to be united with God.
\end{abstract}

Keywords: Erich Fromm, erotic love, love to God, contextual meaning, shift

\section{INTRODUCTION}

Ridho or Ahsanur Ridho, his full name, is the main character in this novel. He was a boy from Tridadi village, Kalirejo subdistrict, Central Lampung Regency. He was a student of Bachelor Degree in Al-Azhar University, Cairo. He was a son from a poor family, yet he had a great willingness to study abroad. He was then admitted at Al-Azhar University Cairo, Egypt on a scholarship. However, he was confused to get the money to pay the travelling cost from Indonesia to Cairo since it was excluded from the scholarship. However, his parents strived for their son to be able to study abroad. Finally, Ridho could go to Cairo.

There are many stories which describe and deliberate the events or emotions experienced by humans such as love, misery, fear, maturity, belief, human betrayal of oneself, disillusion, or even old age [1] The novel entitled Balada Cinta Majenun by Geidurrahman El-Mishry tends to tell love stories. The story of this novel tells a lot about Ridho's love life in Cairo and Ridho's love story in his hometown in the last part.

Ridho love is a love of the opposite sex (erotic love) and then turns into love to God that is based on his knowledge about tharikat science he learned. His love story has a unique meaning because there has been a shift from erotic love to the divine one. 
The expression of falling in love experienced by Ridho affected his life, in which the forms of excessive love expression had an impact on himself and others. Love can be appreciated through literary works like drama, music, short stories, poetry and so on [2]. It happens to Ridho when he is in love with Nisa. He writes the verses as his love expressions.

Love is a universal, sentimental and interesting concept to discuss. According to Erich Fromm, this universal love is then called a brotherly love. It is love among fellow humans that is fundamental and essential for all kinds of love. This love is underlying erotic love, while erotic love is exclusive focusing only on one person of the opposite sex [3].

There are many love events that Ridho has while he is studying at Al-Azhar University. His love story showed a different attitude before he loved Nisa. This was influenced by his unrequited love. As a result he behaved like a crazy person and said something just like a poet. His mental condition was in trouble and his face looked like a dazed person. Even he refused to eat for days, thus; he was fed. One day his brother decided to lock him up in the room because of his abnormal mental condition. He sometimes also endangered the family. Even so, he was still fed, but he kept refusing. Finally he passed away.

The sign of love that Ridho received from his dream convinced him that Nisa was his soul mate. This dream interpretation later became the foundation to keep on pursuing Nisa, even though Nisa did not love him. Because of his excessive love for Nisa, Ridho's life was full of love expressions. This situation brought extreme psychological impact that led to the emergence of vandalism - conscious action of destroying public property and private property for no clear reason - trying to suicide.

Under this condition, Ridho experienced changes in attitude in his daily life. This change was triggered by the external factor, unrequited love by a loved one. Love that should have been able to provide happiness turned out to bring misery for Ridho. Because of his inability to deal with the problems, he surrendered to the Lord. Many people believed that Ridho suffered from a mental disorder. This submission was derived from the basic concept of religion which he learned while studying in Cairo that is called tharikat. At the end of the day his love failure took him to the path of God, but his inability to control himself in the God's path brought a bad impact on him. He was willing to unite himself with God and he believed that the only way was the death.

The problem that Ridho had was the shift from erotic love into divine love. It is the one that makes the writers interested in doing the research. In addition, this novel has never been studied using Erich Fromm's theory of love. Considering the condition of the main character's love, the researchers used the psychology of literature to look deeply on Ridho's psychological condition. Psychology of Literature discusses the types and laws of psychology applied in literary works [4]. The aim of psychology of literature is to understand the psychological aspects included in a literary work. Literature review is a study that examines the reflection of psychology of the characters presented in such a way by the author so that the reader feels lulled by the psychological problems of the story and even feels for being involved in the story [5]. Because what is being examined is the mentality, and love is an action and mental strength, love felt by Ridho was observed using the psychology of literature based on the love concept of Erich Fromm.

Erich Fromm states that love is divided into five: brotherly love, motherly love, erotic love, self- love, and God love. Erotic love has been studied by Suhailah Naili Salsabila [6]. The novelty in this study is the meaning of the love shift of a lover from erotic love to God love. It is the focus and also the reason why the writers use Erich Fromm's theory of love. To get the meaning of the main character's love, the researchers used an approach on psychology 
of literature and analyze it based on the characteristics of Erich Fromm's theory of love. These are the problems that will be revealed by the researchers.

\section{METHOD}

This study is a content analysis using a psychology of literature approach. The data source is Balada Cinta Majenun novel by Geidurrahman El-Mishry. The data used is the text in the novel. The techniques to analyze the data are reading, taking notes, and grouping the data based on the two objects of Erich Fromm's love: erotic love, love for the opposite sex with the desire to be fully united with the one who is loved, and divine love, the desire fulfillment to overcome alienation and to achieve union with God [3]. Furthermore, the data were interpreted using contextual meaning.

\section{RESULT AND DISCUSSION}

Meaning is a definition or concept which is owned or contained in a linguistic sign [7]. In addition to the meaning of language, there are other meanings, such as meaning in life, the simplest example is the meaning indicated by a symbol or traffic signs; traffic lights, zebra cross, and road markings [8]. In semiotics all systems and rules relating to signs have sense or meaning [9]. Different in semantic. Meaning has several types, they are lexical meaning, grammatical meaning, and contextual meaning. In this study the writers used contextual meaning to interpret Ridho's love. Contextual meaning is a meaning based on the context of a particular situation [8].

Love is the highest feeling of love, then under love there is another feeling that is love and the lowest is like [10]. Erich Fromm [3] reveals that love is an attitude, a character orientation that determines the personal relationship of the whole world. It does not lead to one single object of love. Then he divides the object of love into five; brotherly love, motherly love, erotic love, self-love, and God love. What happened to Ridho was brotherly love, erotic love, self-love, and love to Allah. Since this novel tells more about the love story of Ridho to Nisa and ends with Ridho's death, this study only focused on the meaning of erotic love that turns into love to the God.

Erotic love is love to the opposite sex with the desire to be fully united with the loved one. The major characteristic of this love according to Erich Fromm is willingness [3]. It is a willingness to love only one person erotically but still love the others as brotherly love. The love perfection of erotic love is marriage. Love for the opposite sex happens to Ridho, but it is unrequited one.

To overcome the alienation in his erotic love, Ridho uses his hunch to see a love sign to Nisa. The love sign then changes his love point of view for Nisa, which in fact turns out to be divine love. The sign used by Ridho to still love Nisa is the dream. From the sign and the shift of love, there are four major meanings; unwillingness to fail, strong feeling, God's path, and union with God.

\subsection{The Unwillingness to Fail}

First of all, Ridho expressed his love for a girl who was his junior when studying in Islamic boarding house in Jombang. Her name was Afifah. Unfortunately, she rejected his love because she argued that she was still a freshman in the university and just moved to Egypt for a few months. Hence, she had not thought about love matter. Ridho then was hurt by the love rejection from Afifah. 
Then, Ridho expressed his love for a girl from West Java. Her name was Ani Laily. For the second chance, Ridho did not want to fail again. Unluckily, he had to experience disappointment again because Ani claimed that she was in relationship. These two facts show that Ridho never has requited love. Ridho is only at the stage of expressing love and ending up with rejection.

Of the two rejection of love, Ridho began to form the concept of love. The concept he knew is "it is better rather than hiding the love feeling that can torture him. Someone will not be able to understand love, if he does not express it, doesn't he? It is like someone who will not feel the sweetness of wine, if he does not taste it." [11]. For the third time, Ridho did not want to fail again. The third girl is Eva Ratu Nisa. Nisa was the chairwoman of Wihdah, an organization that houses all Indonesian students in Egypt [11].

\subsection{The Strong Feeling}

Along with the journey of his life, since Ridho expressed his love to Nisa, he often experienced some incidents and he associated them with his feeling. Ridho believed in his dream that Nisa was his soul mate. His thought on the dream was a sign of true love based on his knowledge of the meaning of life from tharikat that he had ever learned.

Aristotle describes a dream as a psychological phenomenon during sleep, while Freud assumes that sleep is a condition which has nothing to do with the external world and is a withdrawal from reality [12]. Therefore, it can be stated that Ridho's dream cannot be described as the sign of love.

First dream;

"Painted very clearly on his head, the girl's face is Eva Ratu Nisa, the girl currently participating Nadi Wafidin tour group to Luxsor." [11].

Second dream;

"Wan! I want to tell you," Ridho started breaking the silence. [11].

Third dream;

"Ah...there are no people, it's only me!"

"Her smile has distracted my dream."

"When?"

"When I fell asleep in the car while waiting for Mr. Ardiansyah."

[11].

Fourth dream;

"After a moment, he dreamed about Nisa. In his dream, he was in a village where he had spent more than half of his life. He believed that it was a sign." [11].

Fifth dream;

"Yes, more than that," he paused for a moment, then continued his story, "Last night an angel came to my room and he said that you have been married to someone. In addition, he said that Nisa was a woman chosen by God to accompany me. She's my wife, my wife, bro!” [11].

Sixth dream;

"A few days ago he'd just dreamed about the angel again. The dream was considered as a credence that Nisa might not go home with him and she would be picked up by the prince of God's guardians. And they would welcome the couple."

Seventh dream;

"He intentionally did not visit Nahdhatul Ulama Secreatriat to meet the Mubasyir. Based on his dream, he must be alone." [11].

Ridho got a sign of love from a dream that he got married to a woman. He believed that the woman was Nisa. The sign became obvious as Ridho dreamed that he had been married to Nisa by an angel and he considered it as a real thing. 
What was said by his Mursyid had become his guidance.

"Everything happening on this Earth is not by coincidence because God has planned for the people. Therefore, people must follow their soul to get what they want. God has granted a language understood by themselves in every soul. People only need to recognize their own soul, then follow what has been directed at them?" [11].

The dream is considered as the language of God in which God has given guidance through his dream. According to Ridho, dreams are the language of God. He believed in dreams because he had learned much about the signs of life.

"I have learned a lot about the signs, and also my dream, Gus. I'm sure God has chosen her as my soul mate, Gus. Whatever you say! If you want to say I'm crazy, I'll accept it. Falling in love makes people crazy, doesn't it? And nothing is more sincere than the feelings of crazy people." [11].

In fact, Ridho's love did not have any response from Nisa. This is based on his view of love. At first, his love focused on Nisa as a form of erotic love, then slowly he realized that his love was for God's will, so his life was more on acts of worship. The signs of love that the main character attained from him dreams increased his worship intensity, getting closer to God. It is different from Ekarini Saraswati's research [13]; love to the opposite sex made the individual negligent in loving the God.

\subsection{The God's Paths}

Ridho's life view changed and he surrendered his life to God. He perceived his life merely to God. This can be seen in the text.

"Ridho intends a life in the hereafter, so he really feels the pleasure of the sufficient material world as it is a cycle of nature on God's will. Yes! At the time dzikir in halaqah tharekat assembly, he truly feels a real pleasure. This affects the view of his daily life even in his life of love." [11].

By following tharekat, Ridho felt that there was a change in his view of love. Ridho's life was more dominant with religious nuances. This shows that Erich Fromm's concept of God's love exists. At first Ridho was in love with Nisa to overcome the alienation between himself and Nisa for being alienated from God. Hence, to experience God's love, Ridho walked along the God's paths as religious beliefs of God's love.

"If you want something with all your beliefs that God is the Most Gracious and the Most Merciful, he definitely gives you. Do not revoke your will as long as it is for good! "The two mursyid messages came into his mind alternately. [11].

Therefore, he felt that he still had a chance to realize his destiny to marry Nisa, and Nisa had not married yet at that time. Seeing the reality, his belief in his dreams was getting greater, that dreams are the language of God, and a sign or hunch on someone to make an effort - to try - to find or understand something used as a sign. [11].

\subsection{The Union with God}

Gradually, Ridho felt a strong feeling from God's paths he did. Ridho considered God as his lover, a lover of the Most Beloved. This can be seen in the poem that Ridho expressed;

Dear my Most Beloved,

Thou blessed my love,

Until the bright lights

In a face frame,

Dear love my Nisa. [11] 
Ridho created the concept of a love having a grateful feeling meeting "the Beloved" one. Love makes happy and gives satisfaction. This is influenced by his mursyid who had spoken about God's love. Creating a happy feeling means giving a positive feeling. Then, a meeting with the loved one proves that self-alienation will be overwhelmed.

"Love certainly creates a happy feeling meeting 'The Loved One', then it cannot appear in wishful thinking. This is what distinguishes love in general and love in the sense of ma'rifat to God. Love for someone can be felt by thinking his face, his hair, etc. - erotic love. On the other hand, love for God is not the same way, it must be proven by His obedience in acts of worship, and love to meet God must be kept in one's heart until later in the hereafter." [11].

At that time, Ridho became closer to God. The effort to meet God was getting stronger. He felt that putting an end of worldly life could overcome his alienation from God; the fulfillment of the desire to unite with God. Ridho made a mistake though.

"If Ridho wants to eat, it doesn't matter. In an unconscious feeling, he forgets to eat, yet he doesn't want to eat anything. Does this make sense if we let him to do so?" [11].

We ourselves understand what we want. Conveying meanings in speech and actions might not be easily accepted and even understood. The data shows that Ridho did not want to eat. At this point, what Ridho did was one of his attempts to end his life to unite with God.

\section{CONCLUSION}

The shift in love experienced by Ridho was influenced by the concept of love embedded in his mind. The desire to keep chasing love is a sign of the love he received from his dream. Later, he saw his dream with the concept of love from the learning books and tharikat. Learning does need a teacher, actually it cannot only be done by reading a book then applying it in a real life. As a result, Ridho continued imposing his will to marry Nisa. The successful love relationship that Ridho hoped was a marriage in which he married to the loved one and succeeded in struggling with his love. The path of religion that he took, from love to His creatures that led to the path of God, gave rise to the desire to be united with God. At the end of the day, there was a growing belief that union with God can be achieved with death.

ACKNOWLEDMENT: The autor wishes to thank the Directorate General for Research and Development, Ministry of Higher Technology Research and Education, 28/SP2H/DRPM/LPPM.U J/III/2019.

\section{REFERENCE}

[1] R. Stanton, Teori Fiksi Robert Stanton, Cetakan Ke. Yogyakarta: Pustaka Pelajar, 2012.

[2] T. Imaningtyas, Intan; Atmoko, Adi; Triyono, "Pengekspresian Jatuh Cinta Siswa Sekolah Menengah Pertama Melalui Media Tulisan: Kreativitas atau Vandalisme?," J. Kaji. Bimbing. Dan Konseling, vol. Vol 2, No, 2017.

[3] E. Fromm, Seni Mencintai. Yogyakarta: Basabasi, 2018.

[4] M. Budianta, Teori Kesusasteraan Rene Wellek Austin Warren. Jakarta: Gramedia, 2016.

[5] A. Minderop, Psikologi Sastra. Jakarta: Buku Obor, 2013.

[6] S. Naili Salsabila, "Cinta Erotis Andien Kepada Wibianto Pada Novel Ssisi Gelap Cinta Karya Mira W,” vol. Volume 01, 2012.

[7] A. Chaer, Linguistik Umum, Revisi. Jakarta: Rineka Cipta, 2014.

[8] A. Chaer, Kajian Bahasa: Stuktur Internal, Pemakain dan Pembelajaran. Jakarta: Rineka Cipta, 2013. 
[9] S. Tri Suryani Dewi, "Makna Cinta dalam Kumpulan Puisi Wakanashu karya Shimazaki Toson Berdasarkan Teori Struktural-Semiotik," Japanology, vol. VOL. 5, NO, 2017.

[10] F. Nurbaiti, "Bentuk-Betuk Tuturan Penolakan Cinta dalam Bahasa Indonesia dan Faktor Sosial yang Mempengaruhinya Analisis Sosiolinguistik," ETNOLINGUAL, vol. Vol 1 No 2, 2017.

[11] G. El-Mishry, Balada Cinta Majenun. Yogyakarta: Citra Media, 2008.

[12] S. Frued, A General Introduction To Psychoanalysis. Yogyakarta: Indoliterasi, 2015.

[13] E. Saraswati, "Makna Cinta dalam Novel dari Lembah Ke Coolibah Karya Titis Basino: Sebuah Telaah Semiotis," J. Artik., vol. Vol 6, No, 2008. 